甲田 茂樹*1, 久繁 哲德*2, 小河 孝則*1, 車谷 典男*3
出島 牧彦*3, 宮北 隆志*4, 小寺 良成*5, 濱田 裕久*1
中桐 伸五*6, 青山 英康*1

\title{
AN EPIDEMIOLOGICAL STUDY ON LOW BACK PAIN AND OCCUPATIONAL RISK FACTORS AMONG CLINICAL NURSES
}

\author{
Shigeki KODA, ${ }^{* 1}$ Akinori HISASHIGE,*2 Takanori OGAWA,*1 \\ Norio KURUMATANI,*3 Makihiko DejIMA,*3 Takashi MiYakita,*4 \\ Ryosei KODERA, ${ }^{* 5}$ Hirohisa HAMADA,*1 Shingo NAKAGIRI*6 \\ and Hideyasu AOYAMA*1
}

\begin{abstract}
Recently medical services and nursing system are being reformed due to high medical costs and shortage of clinical nurses. The shortage of clinical nurses influences not only their working conditions but also their own health problems. In European countries and the United States, low back pain (LBP) has been reported to be one of the most common and costly health problems among clinical nurses.

To estimate the occupational risk factors of LBP among nurses, a questionnaire survey of LBP and occupational risk factors was carried out in 1987 on 947 clinical nurses and as well as on 300 female clerical workers of three local goverments. First, to examine the prevalence and the magnitude of the problem, we analyzed several kinds of prevalence rates of LBP and its characteristics among nurses and clerical workers. Second, a case-control study was conducted to investigate the relationship between LBP and occupational risk factors. In analyzing occupational risk factors of LBP, odds ratios, age adjusted odds ratios and $95 \%$ confidence intervals were computed. Finally, to estimate simultaneously the effect of multiple risk factors of LBP and to confirm univariate age adjusted odds ratio analyses, several multivariate analyses were performed.

Point, period (a month), and lifetime prevalence rates of LBP and prevalence rate of severe LBP among clinical nurses were significantly higher than those of clerical workers $(p<0.05-0.001$, respectively). Demographic and occupational items, such as being an assistant nurse (as opposed to a registered nurse), and working in certain departments (internal medicine, orthopedic surgery, neurosurgery, psychiatry, tuberculosis ward) showed significantly higher odds ratios for LBP ( $p<$
\end{abstract}

*1 岡山大学医学部衙生学教室

*2 高知医科大学公家衛生学教室

*3 奈良医科大学公竬徫生学教室

*4 熊本大学医学部衛生学教室

*5 高知県本山保健所

*6 全日本自治団体労倒組合安全衛生対策室 平成 3 年 3 月 13 日受付

*1 Department of Hygiene and Preventive Medicine, Okayama University School of Medicine

*2 Department of Public Health, Kochi Medical School

*3 Department of Public Health, Nara Medical School

*4 Department of Hygiene, Kumamoto University, School of Medicine

*5 Motoyama Health Center, Kochi Prefecture

*6 Occupational Health and Safety Unit, All Japan Prefectural and Municipal Workers' Union Received for publication, March 13, 1991 
0.05-0.001, for all). Many items pertaining to working conditions connected with shift work, hospitalized conditions of patients, taking breaks and holidays, working postures, weight of patients and equipment lifting and moving, working environments and so on had significantly elevated age adjusted odds ratios $(p<0.05-0.001$, for all). Intensity of work loads estimated subjectively such as 'caring for patients who are in bed', 'supporting patients when transporting and bathing them', 'preparing drugs and injections, and treating', 'observing and monitoring patients' conditions', 'instructing and explaining procedure to patients and their family' and so on also had significantly elevated age adjusted odds ratios $(p<0.05-0.001$, for all). Moreover, many items on the problems connected with working life and interpersonal relationships showed significantly higher age adjusted odds ratios $(p<0.05-0.001)$. In multivariate analyses, independent variables which made a significant contribution to the model were similar to the items which had significantly elevated age adjusted odds ratios. In summarizing these results, many independent variables were related to shift work, physical nursing work loads and mental stress in caring for patients. It is noteworthy that not only direct influences from occupational factors but also indirect influences from their effects on workers' lives were observed.

These results suggest a positive relationship between nursing work load and LBP. Therefore, it is recommended that working conditions and work loads of clinical nurses as mentioned above be improved in order to prevent LBP and promote the quality of nursing services.

Key words : clinical nurse; low back pain; occupational risk factor; case-control study ; multivariate analysis

\section{I . 粕 言}

かが国の医療は急激炕進行する人口の高龄化，国民医 療費の增大などにより，提供する医療サービスのあり方 をめぐり大きな転換期にさしかかっている。.このよらな 状況下，厚生省・国民医療総合対策本部は 1987 年 6 月 に提出した中間報告の中で，質の良い医潦サービスを効 率的に供給していくためのシステムつくりを提唱して括 り，国民の健康を守るといら使命を持つ保健医療促事者 に奇せられる期待には大きいるのがある゙。.

近年の医療技術の高度化やニーズの多様化に的確に対 応するためには，看護婦をはしめとする各種の看護職に 従事する人員の質的扰よび量的確保が最大の課題であ る. 1987 年の日本看護協会の病院看護基礎調查によると 「入院患者 2.44 人に 1 人の看蓝婦，准看護婦」とい5 結果が出され，医療法施行規則第 19 条の 4 の基準を大 幅に上回っているとしているが，看護婦の行っている夜 勤回数は 1 人当り 1 か弗平均 8.6 回となっており，1965 年の人事院の判定で示された「1 1 月 8 回以内」より依 然として多く，看護婦の增員や看護体制の整備が不十分 である2ことがうかがえる.

一方，赤字経営脳む自治体立病院では，病院経営健 全化と合理化を行らため，人員定数の削減，臨時ないし パート職員の採用，民間委託の推進を図っておう，病院 職員の大多数を占める看護婦の労働負担の增大が推測さ れる.

このような状況に対応して, 看護業務との関連から,
交代制勤務のあり方と疲労症状 ${ }^{9 \sim 6)}$ ，対人業務を中心と した職業性ストレスと心身の健康状態 6 14)，直接ないし 間接看護業弱に伴ら作業負坦と身体局所の痛みの゙および 大看護単位の導入々提供する看護水準 ${ }^{15} な と ゙$ 看護婦の労 働条件，作業条件，健康問題ならびに看護の質に関して 数多くの調查報告が出されるようになった．また，欧米 を中心として従来より看護業務内容との関連が強いとさ れている職業性腰演症に関しても多くの報告 ${ }^{16 ~ 25) か ゙ な ~}$ されている.しかしながら，わが国で性業性腰痛症に 関して, 看護業務との関連で度学的な検討を行った報告 は少ない。

したがって，看護婦に多発している職業珄腰痛症につ いて, 発症に関与する職業性要因を疫学的济調査し, 発 症予防や対策に役立てることは，産業保健学上重要であ るばかりでなく，看護に伴ら労㗢負担の軽減を図ること が看護の質や量の改善につながるといら視点に立つなら ば，今後のわが国の看護サービスの向上を図る上でもそ の意義は大きいと考えられる。

\section{II. 研 究 目 的}

職業性腰痛症の発症要因は多く，たとえ職業性要因に 限っても, 単一の発症要因に帰着させることは困難であ る. 発症に影響を与えるいくつかの要因が複雜に関連し 合いながら，職業性腰痛症を発症させていることは明ら かである 26-311。

看護婦の職業性腰痛症発症について, 学偎条件, 作業 環境，交代制勤務をはじめとする労働態様，介護負担や 
作業姿勢などの作業条件および勤務生活上の問題点など を把握し，職業性腰痛症発症と職業性要因との疫学的な 検討を行い，その関連性について明らかにしたいと考え た。さらに，今後の予防対策の確立に向けた基碟資料を 得るためにる，嬂業性腰痛症の有訴状況の有無により症 例一対照研究を行い，職業性腰痛症発症と各要因との関 連の強さを定量的に評価したいと考えた。

\section{III. 研究対象および方法}

近年，医療技術の進歩は目筧ましく，「チームナーシ ング」を中心とした看護業務の分業化が進みつつあ $3^{32,332}$. その結果として, 身分, 資格执よび所属病棟に よって看護婦の職務内容, 労働形態や作業条件が異なっ てくることが考えられる.ささらに, 看訬婦の所属する病 院の立地条件や背景，役割や機能，国公私立の別が看護 業務内容に影響を与えている342。そのため調查には，全 国の人口 20 万人から 50 万人規模が地方都市で中核病院 として位直つけられている病床数の 300 床から500 床規 模の市立粉合病院を四つ選び，勤務する看護婦全員 947 名を調查対象とした。

対照群としては, 家事労働の負担を伴うことの共通性 はあるが，業務としての看護作業の負担がなく，地域性 を考慮し, 社会的にも経済的にも条件を同じくする地方 公務員を選定し，調查への協力が得られる同一自治体に 勤務する女子事務職員（以下，事務員とする） 300 名を 選んだ.

調查方法としては，多角的な偉康状態に関連する情報 を網羅的かつ能率的に把握するために質問紙法 ${ }^{35)}$ を採用 し，留め置き法によって，病院および自治体単位ごとに 質問紙の配布ならびに回收を行った、看護婦および事務 員双方とも調查時期を合わせ，1987 年 2 月に実施した.

職業性腰痛症（以下，腰痛症とする）発症と職業性要 因との関連を疫学的に検討するためには, 結果にかかわ る全ての要因のらち，看護業務に関連する要因をできる だけ網羅する必要がある.そこで, 質問紙法の調査項目 には, 看護婦の年齢, 勤続年数, 婚姻状況, 子供の数お よびその年齢，住居执よび通勤状況，家事および育児の 負担状況, 看護婦の資格および職位, 所属病棟などの属 珄に関する項目に加えて, 交代制勤務の有無拉よび夜勤 回数, 労働時間, 残業時間, 所属病棟の患者および看護 婦数, 担送・護送患者数, 夜勤時の休咊や仮眠などの取 得状沉, 仮眠室の設置状況, 生理・育児・年次休㗇の取 得状沉など労働態様や労働条件に関する項目, 騒音, 暑 さ，寒さや作業場の狭さなどの作業環境に関する項目， 勤務生活に関する項目，各種看護作業に伴ら精神的およ
び身体的負担の程度，勤務中の休媳取得状況，不自然な 作業姿勢の出現頻度，患者の抱き抱え中重量物の取扱い 状況，看護作業中の心理状態や問題点など作業条件に関 する項目，夜勤や教育制度などに関する勤務体制の改善 要求などの項目を選定した。

また，腰痛症に関する調査項目には，日本産業衛生学 会腰痛委員会の「腰痛診断のための問診表」36) を自記式 に改訂して用い，腰痛症の発症の仕方や重症度について は Nachemson $5^{372}$ の classification of low-back pain を参考にして改訂して用いた。

回収された調查表は看護婦が 898 名（回収率 94.8\%)， 対照群である事務員が 255 名（回収率 85.5\%) であっ たが，分析対象には性別および年龄の明らかなるのを用 いたなお，看護婦と事務員の要因-対照㸴究を行う際 は，年龄を 5 歳階層別にそれぞれ数の少ない事務員に合 わせて 1 対 1 の割合で 247 名ずつ無作為層化抽出し, 比 较する両群の年齡構成を等しくして検討した ${ }^{38 \sim 411}$.

さらに，腰痛症発症と職業性要因の関連との強さの程 度を定量的に評価するために，腰痛症有訴状況のらち point prevalence の訴之のあるむので period prevalence の “always” とする看護婦 108 名を症例群と $し$, point prevalence および period prevalence の訴 えのない看護婦 309 名を対照群として, 症例一対照研

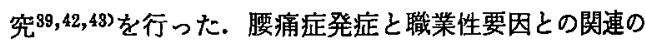
強さの指標としては，各要因ごとの odds ratio(2,43) 算出して検討を行った。 ただし，看護婦の属性以外の要 因については，年龄要因を交絡因子 (confounding factor) とみなし, 年舲を 29 歳以下, 30 39 歳, 40 歳以 上の 3 群にあらかじめ分類 し, age adjusted odds ratio ${ }^{43}$ を算出して検討することとした。

最後に，腰痛症発症と職業性要因との関連性を総合的 に評価するために，ダミ一変数として腰痛有訴群である 症例群に 1 , 腰痛非有訴群である対照群に0 0 を与えて, 重回㷌分析のステップロイズ法, 判別分析法, 林の数量 化 I 類および而類を用いて検討した45 47). 看護㭿の年龄 および勤続年数の要因については，とくに症例群と対照 群との間の一致を行わず，職業性要因の一つとして㴗痛 症発症との関連を検討した.

なお，調査表の集計および分析にめたっては，岡山大 学総合情報処理センターの SPSSX ヘッケージ STAT ペッケージを用い48)，訴え率の統計学的有意差検定には $\chi^{2}$ 検定を, age adjusted odds ratio の統計学的有意差 検定には Cochran-Mantel-Haenszel 険定4!を用いた。 


\section{IV. 研究結果および考富}

\section{1. 回答者の属性および労働条件}

回收された調查表のらち，性別および年路の明らかな すのは看護婦 896 名括よび事務員 247 名で，珄別は全て 女性であり，おの打のの平均年龄は看蓝嗄 32.4 墄（標 準偏差 7.8 藏)，事務員 35.8 歳（僄準偏差 8.2 蔵） と事 務員の方が高かった $(p<0.001)$. 看護婦および事務員 の属性をTable 1 に示したが，その年龄構成についてみ ると，看護婦は 20 䠞代後半が最も多いのに対し，事務 員では 30 藏代後半にピークを示す一峰性の分布を示し ていた：また，平均看護経験年数は 10.6 年（標準偏差 7.4 年)であり,このうら現在所属している病院での平 哅勤続年数は 8.3 年（梆準偏差 6.4 年）となっていると ころから，対象者の多くが就職した病院に継続して勤務 しているるのと考学られた。

職種についてみると一般看護婦 $83.5 \%$, 総婦長・婦 長·主任 $6.1 \%$, 臨時・パート $5.5 \%$, 助産婦 $3.2 \%$ であ った. 所属については内科病棟が $22.6 \%$ で最も多く， 一般外来 $16.5 \%$, 外科病棟 $9.7 \%$, 整形外科病棟 $9.6 \%$, 産婦人科病棟 $9.5 \%$ ，小児科病棟 $9.4 \%$ ，脳外科病棟 8.4 $\%$, 泌尿器科病棟 $7.3 \%$, 眼科病棟 $6.8 \%$, 耳鼻咽知科 病堜 $6.6 \%$, ICU $6.5 \%$, 皮居科病楝 $6.0 \%$, 伝染病科 病棟 $3.0 \%$, 救急外来 $2.6 \%$, 精神科病棟 $1.4 \%$ となって 牧り，ほぼ全ての診療科が存在し，総合病院の特色が出 ていた. なお，病棟での診療科目が複数にわたる場合が 存在するため, 各病棟の診療科目の合計は $100 \%$ を上回 っている.

勤務形態については常日勤 $21.3 \%$, 三交代制勤務 68.2 $\%$ ，変則三交代制勤務 8.1\% で常夜勤のるのはいなかっ た. な版，変則三交代制勤務とは通常の準夜・深夜勤務 飞当直の加わったものを指す。1 か月の準夜・深夜勤務 の平均回数はそれぞれ準夜 4.2 回（標準偏差 1.3 回）, 深夜 4.1 回（標準偏差 1.4 回）で，準夜と深夜を合計し た平均夜勤回数は 8.3 回（標準偏差 2.1 回）と前出の日 本看護協会の病院看護基礎調查結果（1987 年）の8.6 回 に比べるとやや少ないるのの，1965 年になされた人事院 の判定の 1 か月の夜勤回数 8 回以内を上回るものが全体 の交代制勤務者 691 名 (76.9\%) の $31.5 \%$ む打り，勤 務生活および健康，性の保護を目的とした夜勤回数の 制限が徹底されていないことが認められた。

一方，事務員は全体の $82.0 \%$ が市役所勤務で，残り は福祉事務所，病院事務であった．その業務内容をみる と VDU 作業 $35.1 \%$, 複写作業 $29.1 \%$, 電話交換 7.2 $\%$ タイプ $4.8 \%$ ，パンチ $4.4 \%$ と座位作業を中心とし
Table 1. Comparison of age, marital status, family and housekeeping between hospital nurses and clerical workers.

\begin{tabular}{|c|c|c|}
\hline & $\begin{array}{c}\text { Hospital } \\
\text { nurses } \\
n=896 \\
\left(\begin{array}{c}n=247) \\
(\%)\end{array}\right.\end{array}$ & $\begin{array}{c}\text { Clerical } \\
\text { workers } \\
n=247 \\
(\%)\end{array}$ \\
\hline \multicolumn{3}{|l|}{ Distribution of age } \\
\hline$-24 \mathrm{yr}$ & 19.0 & 10.4 \\
\hline $25-29$ yr & 25.7 & 12.0 \\
\hline $30-34 \mathrm{yr}$ & 20.8 & 23.1 \\
\hline $35-39$ yr & 17.8 & 33.6 \\
\hline $40-44 \mathrm{yr}$ & 8.6 & 8.1 \\
\hline $45-49 \mathrm{yr}$ & 4.5 & 4.0 \\
\hline $50 \mathrm{yr}-$ & 3.3 & 9.6 \\
\hline \multicolumn{3}{|l|}{ Marital status } \\
\hline Single & $39.8(25.5)$ & 22.3 \\
\hline Married & $56.9(70.9)$ & 74.9 \\
\hline Divorced & $2.8(3.2)$ & 2.4 \\
\hline \multicolumn{3}{|l|}{ Number of children } \\
\hline No children & $49.0(36.4)$ & 31.2 \\
\hline One child & $12.9(12.6)$ & 14.6 \\
\hline Two children & $28.8(36.0)$ & 43.3 \\
\hline Three or more children & $8.1(12.9)$ & 8.9 \\
\hline \multicolumn{3}{|c|}{ Number of children below $3 \mathrm{yr}$} \\
\hline One child & $13.0(14.2)$ & 15.0 \\
\hline Two or more children & $4.3(6.5)$ & 4.0 \\
\hline \multicolumn{3}{|l|}{ Housekeeping } \\
\hline Mainly responsible & $68.7(73.7)$ & 73.7 \\
\hline Partially responsible & $30.7(26.0)$ & 25.9 \\
\hline
\end{tabular}

た作策が多く，全貣が日勤勤務者であった。

看護婦之事務員両群の結婚，子供の数および家事負担 の状況については，看護婦の平均年蹫の方が事務員に比 べて低いため，「未婚者」拉よび「子供なし」の割合が 事務員に比へて高かったが，年龄構成を一致させて比較 すると，結婚，子供の数， 3 藏以下の子供の数战よび家 事の負担状況では両群とす同様の比率構成となった。こ のことは女性の健康問題を検討する場合，勤務負担と同 時に青児や家事負担を同様に考虑しなければならないと いら社会的な状沉を示唆しているものであるが，今回の 看護婦と事務員との間で腰痛症発症に関する要因一対照 研究を行う際には，両群の育児や家事負担の影響の度合 いは同じ程度であり，調查における両群の比較検討の可 能性は高いと考えられる。 
Table 2. Comparison of working postures and heavy lifting between hospital nurses and clerical worker.

\begin{tabular}{|c|c|c|c|}
\hline & \multicolumn{2}{|c|}{$\begin{array}{c}\text { Hospital nurses } \\
n=896(n=247) \\
(\%)\end{array}$} & $\begin{array}{c}\text { Clerical workers } \\
n=247 \\
(\%)\end{array}$ \\
\hline \multicolumn{4}{|c|}{ Working postures } \\
\hline Squatting & $66.9 / 93.5^{a}$ & $(67.2 / 95.1)^{* * *}$ & $8.1 / 30.0$ \\
\hline Twisting & $37.1 / 80.6$ & $(34.8 / 79.3)^{* * *}$ & $2.4 / 17.0$ \\
\hline Bending & $31.6 / 74.3$ & $(30.8 / 73.3)^{* * *}$ & $2.4 / 12.5$ \\
\hline Standing & $94.4 / 98.0$ & $(93.5 / 97.1)^{* * *}$ & $17.0 / 47.0$ \\
\hline Heavy lifting & $69.4 / 93.3$ & $(64.4 / 93.5)^{* * *}$ & $1.2 / 14.2$ \\
\hline \multicolumn{4}{|c|}{ Weights of patients and equipment lifting and moving } \\
\hline $60 \mathrm{~kg}-$ & \multicolumn{2}{|c|}{$5.8(8.1)$} & 0.0 \\
\hline $60-40 \mathrm{~kg}$ & \multicolumn{2}{|c|}{$32.4(33.2)$} & 0.0 \\
\hline $40-20 \mathrm{~kg}$ & \multicolumn{2}{|c|}{$33.2(31.6)$} & 0.0 \\
\hline $20-10 \mathrm{~kg}$ & \multicolumn{2}{|c|}{$15.7(12.1)$} & 2.8 \\
\hline$-10 \mathrm{~kg}$ & \multicolumn{2}{|c|}{$7.7(4.9)$} & 57.9 \\
\hline
\end{tabular}

Note \& prevalence rate of 'always'/'always' and 'sometimes.' $\chi^{2}$ test, *** $p<0.001$.

Table 3. Prevalences of low back pain among hospital nurses and clerical workers.

\begin{tabular}{|c|c|c|}
\hline & $\begin{array}{c}\text { Hospital } \\
\text { nurses } \\
n=896 \\
(n=247) \\
(\%)\end{array}$ & $\begin{array}{c}\text { Clerical } \\
\text { workers } \\
n=247 \\
(\%)\end{array}$ \\
\hline Point prevalence & $35.5(37.7)^{* *}$ & 24.3 \\
\hline \multicolumn{3}{|l|}{ Period prevalence } \\
\hline Always & $12.5(13.8)^{* * *}$ & 4.0 \\
\hline Always +Sometimes & $64.4(67.6)^{* * *}$ & 37.6 \\
\hline Lifetime prevalence & $72.6(81.8)^{* * *}$ & 46.2 \\
\hline \multicolumn{3}{|l|}{ Onset of low back pain } \\
\hline Acute & $23.4(27.1)^{* * *}$ & 5.3 \\
\hline Chronic & $65.7(64.1)$ & 81.6 \\
\hline \multicolumn{3}{|c|}{ Conditions of low back pain } \\
\hline $\begin{array}{l}\text { Severe LBP resulted in } \\
\text { and breaks at work }\end{array}$ & $\begin{array}{l}\text { n absence from } \\
3.8(5.7)\end{array}$ & $\begin{array}{r}\text { work } \\
2.6\end{array}$ \\
\hline $\begin{array}{c}\text { Severe LBP, even if ne } \\
\text { absence nor breaks }\end{array}$ & $\begin{array}{l}\text { ither resuled in } \\
22.9(19.8)\end{array}$ & 10.5 \\
\hline Light LBP & $52.5(55.2)$ & 56.1 \\
\hline No problem & 18. $3(18.8)$ & 28.1 \\
\hline
\end{tabular}

\section{2. 腰痛症の有訴状況および作業状況}

看護婦と事務員の作業状況，とりわけ腰痛症発症に関 連すると報告されてきた作業姿勢および重量物取扱いに 関するるのをTable 2 に示した. 作業姿勢については中
腰姿勢，腰部の捻転拉よび曲げ，立位姿勢の出現は明ら かに看護婦の方が多く，事務員との作業内容の違いを反 映していた，重量物の取扱いについてみると，重量物を 取り扱う頻度は看護婦の方が高く，しかもその取扱い重 量において看護婦の方が重い重量を 1 人で取り报ってい た.このことは，看護作業に患者の抱き抱えが要求され るためと考光られるが，1967 年に ILO の「女性の場 合， 1 人で取り扱う重量物の上限は $20 \mathrm{~kg}$ (continuously) と $30 \mathrm{~kg}$ (occasionally)」といら勧告内容を合わせ て考えると, 看護職種が腰痛症などの筋骨格系疾患のリ スクの高い職場であることがうかがわれる.

ついで，看護婦と事務員の腰痛症の有訴状況について は Table 3 に示すごとく，看護婦の方が point prevalence および period prevalence のいずれにおいても 統計学的に有意に高い訴え率を示していた．就労後の腰 痛症発症の経験についても，看護婦の方が亦務員より高 くなって拈り，腰痛症発症の状況をみると両群ともに余 徐に発生したといら慢性発症型の割合が最も多くなって いたが，看護婦では腰痛症経験者の約 4 分の 1 Kあたる るのが「仕事中に急性に発症した」としており，事務員 の発症状況とは異なっていた. 現在の腰痛症の程度は， 「休業·休敗が必要」「休策・休喤は必要ないが,かなりつ らい」とする重症な腰痛症を訴えるすのの比率が看護妇 に多かった，すなわら，看護婦では事務員に比へて腰痛 症の有訴者が多く，腰痛症の起こり方す急性発症のもの が多かった. しかも，重症な腰痛症に悩むるのが看護婦 に多かった。 
久繁 ${ }^{6)}$ は看護婦の腰痛症に関して, 事務員に比ぺて 高い訴㐬を示しており，その原因についても「重量物 の取报い・運搬」「中腰作業」「立ち仕事」を指摘してい るが、今回の研究結果はこれらの報告と一致しており， 重量物取扱いや作業姿勢などが看護婦の腰痛症発症にか かわる作業条件であることを認めた。

3. 看護婦の腰痛吐症に関する症例-対照研究結果 看護婦と事務員との要因一対照研究において，看護作 業と腰痛症発症との関連性については諗められたので, つぎ看護作業の中で発症にかかわるリスクの高い職業 性要因について関連の強さの程度を定量的に評価してお く必要がある考兄た。

看護婦の属性と腰痛症発症との関連について梌討した 結果をTable 4 亿示したが，年㱓扰よび勤続年数では統 計学的な有意差は認められなかったるのの, 40 藏以上の 群が 29 藏以下の群に対して, 勤続年数 15 年以上の群が 1 年未满の群に対して高い傾向にあった $(\boldsymbol{p}<0.1)$. 子 供の数ないし 3 歳以下の子供の数についてみると， 2 人 ないし1人とする群で子供がいないとする群に比べて統 計学的に有意に高い odds ratio を示した. 逆に, 子供 の数ないし 3 歳以下の子供の数が 3 人以上ないし 2 人以 上になると，統計学的有意差は認められなかった. この ことは，子供の数がある程度以上に增えていくと，自分 以外に子供の世話をみてくれる者に賴るため, 育児の負 担はかえって減少するものと考えられる. 看護婦の資格 および所属病棟についてみると, 准看讙婦は正看讙婦に 比へてて，また，内科病棟，整形外科病棟，脳外科病棟,

精神科病棟, 結核病棟では統計的に有意飞高い odds ratioを示していたが，逆に，産婦人科病棟では低かっ た.このことは, 看護婦の資格や所属病楝で看護業務の 制限の有繁, 担・護送患者の人数, 患者の抱き抱克の頻 度などの作業条件が異なるためと考兄られ，看護婦の職 務内容が関与していることが示唆された.

ついで, 看護婦の労働条件に関する検討結果は Table 5 に示すごとく, 勤務形態や労働時間, 残業時間の要因 では統計的有意差は認められなかったが, 夜勤回数では 1か月の夜勤回数が 7 8 回の群が常日勤群に比べて統 計的に有意们高くなっている一方, 夜勤回数が 9 回以上 に䄈ると age adjusted odds ratio は低下していた. ま た，準夜と樑夜勤務の回数を別々に検討しても，1か月 の回数で4 回を境にして同様の結果が認められた。この ことは, 看護婦の中で腰痛症の重症度や状態沁じて, 夜勤回数を減らしたり，常日勤勤務にまわったり，ある いは労働時間や残業時間を減らしたりという health workers effectの関与が考えられた。産前・夝後の育児
Table 4. Odds ratios for low back pain by age, marital status, family, housekeeping and occupational items.

\begin{tabular}{|c|c|}
\hline Items & odds ratio $(95 \% \mathrm{CI})$ \\
\hline \multicolumn{2}{|l|}{ Age } \\
\hline $30-39$ yr & $1.40(0.83-2.37)$ \\
\hline $40 \mathrm{yr}-$ & $1.73(0.90-3.34)$ \\
\hline \multicolumn{2}{|l|}{ Marital status } \\
\hline Married & $1.55(0.94-2.55)$ \\
\hline \multicolumn{2}{|l|}{ Number of children } \\
\hline One child & $1.30(0.60-2.81)$ \\
\hline Two children & $1.72(1.02-2.91)^{*}$ \\
\hline Three or more children & $1.11(0.43-2.80)$ \\
\hline \multicolumn{2}{|c|}{ Number of children (below $3 \mathrm{yr}$ ) } \\
\hline One child & $1.90(1.11-3.24)^{*}$ \\
\hline Two or more children & $1.67(0.89-3.12)$ \\
\hline Housekeeping & $0.80(0.49-1.32)$ \\
\hline \multicolumn{2}{|l|}{ Registration } \\
\hline Assistant nurses & $2.10(1.20-3.72)^{* *}$ \\
\hline Job category (ward) & $1.29(0.53-3.22)$ \\
\hline \multicolumn{2}{|l|}{ Duration of nursing work } \\
\hline $1-5 \mathrm{yr}$ & $1.03(0.40-2.70)$ \\
\hline $5-10 \mathrm{yr}$ & $0.98(0.38-2.56)$ \\
\hline $10-15$ yr & $1.14(0.45-2.93)$ \\
\hline $15 \mathrm{yr}-$ & $2.26(0.82-6.36)$ \\
\hline \multicolumn{2}{|l|}{ Department category } \\
\hline Internal medicine & $1.90(1.10-3.28)^{*}$ \\
\hline Surgery & $1.21(0.52-2.77)$ \\
\hline Obstetrics/gynecology & $0.33(0.10-1.02)^{*}$ \\
\hline Pediatrics & $0.65(0.27-1.52)$ \\
\hline Orthopedic surgery & $2.18(1.09-4.35)^{*}$ \\
\hline Neurosurgery & $2.39(1.13-5.01)^{*}$ \\
\hline Psychiatry & $4.39(0.59-38.04)^{*}$ \\
\hline Tuberculosis ward & $9.27(2.25-44.12)^{* * *}$ \\
\hline
\end{tabular}

$* p<0.05,{ }^{* *} p<0.01,{ }^{* * *} p<0.001$.

休眤に伴 ら代替要員の配置や年次休睱の取得状況。腰痛 症発症に関連していた。病棟の患者の状態については， 担・護送患者や重症患者数が増加すると腰痛定発症関 する age adjusted odds ratio は統計的有意差をるっ て上昇することが認められた. 担・櫒送患者や重症患者 飞対しては，患者の体位交換や抱さ抱占，移動・入浴補 助などの直接的看護を行ら頻度が高く，そのため看護婦 の胘部負担が增加するためと考えられる. 夜勤時の勤務 
Table 5. Age adjusted odds ratios for low back pain by working condition.

\begin{tabular}{cc}
\hline Items & $\begin{array}{c}\text { Age adjusted odds } \\
\text { radio (95\% CI) }\end{array}$ \\
\hline $\begin{array}{c}\text { Shift work } \\
\text { (three-shift system) }\end{array}$ & $2.25(0.91-2.59)$ \\
Working hours (per week) & \\
$36-42 \mathrm{~h}$ & $2.11(0.88-5.05)$ \\
$42-44 \mathrm{~h}$ & $1.94(0.78-4.81)$ \\
$44 \mathrm{~h}-$ & $1.14(0.42-3.08)$ \\
Overtime (hours per month) & \\
$-10 \mathrm{~h}$ & $0.89(0.43-1.84)$ \\
$10 \mathrm{~h}-$ & $1.10(0.49-2.44)$ \\
Number of nights worked (per month) \\
$7-8 \mathrm{~d}$ & $1.96(1.14-3.39) *$ \\
$9 \mathrm{~d}-$ & $1.34(0.66-2.72)$
\end{tabular}

Number of patients carried by stretcher
20 patients-
$2.51(1.44-4.35)^{* *}$

Number of severe patients carried by stretcher

20 patients-

$4.80(1.79-12.87)^{* *}$

Number of severe patients
15 patients-
$1.70(1.03-2.80)$

Lack of breaks during night shift

$\begin{array}{ll}\text { Sometimes } & 1.40(0.81-2.34) \\ \text { Always } & 2.64(1.47-4.74)^{* *}\end{array}$

Lack of break during graveyard shift

$\begin{array}{ll}\text { Sometimes } & 1.76(1.07-2.91)^{*} \\ \text { Always } & 3.22(1.69-6.15)^{* * *}\end{array}$

Lack of night naps during graveyard shift

$\begin{array}{ll}\text { Sometimes } & 1.13(0.61-2.08) \\ \text { Always } & 1.78(1.06-3.01)^{*}\end{array}$

Frequency of night nap time

Seldom $2.16(1.22-3.81)^{*}$

No room for night naps 1.98 (1.25-3.15) ${ }^{* *}$

Condition of room for night naps

$\begin{array}{ll}\text { Noisy } & 2.13(1.11-4.07)^{*} \\ \text { Uncomfortable bed } & 2.34(1.16-4.72)^{*}\end{array}$

No substitute nurse for meternity leave

$1.67(1.07-2.61)^{*}$

Taking paid holidays

Sometimes $\quad 3.00(1.30-6.94)^{*}$

Seldom $3.93(1.66-9.34)^{* *}$

Cochran-Mantel-Haenszel test, ${ }^{*} p<0.05,{ }^{* *} p<$ $0.01, * * * p<0.001$.
条件では，準・深夜の休秘や深夜の仮眠の取得状況，仮 眠設備の設置状況，設置されてある仮眠設備の懪境（虽 音や瘦具の適否）の不備か腰痛症発症に関連していた。 従来の夜勤・交代制勤務に関する研究 ${ }^{40-51)}$ に扣いて, 仮眠や休憩の疲労回復効果が強調されてきたにもかかわ らず，今回の研究結果では，現状行われている夜勒時の 休想や休息，仮眠が質的炕す量的炕す不十分であるた め，通常の看護作業によってもたらされた腰背部の疲学 症状を回復させるだけの効果が認められていないと考兄 られる. 看護婦の夜勤回数の増加户労働条件の悪化の背 景には，看護妌不足が影響しているといわれる2,52,53)か， 逆に夜勤時の勤務条件の不備が改善しない限り，腰痛症 悪化などの健康障害に伴ら看護婦の退職に齿止めかかか らず，悪循環を引き起こす結果となるであるう。

具体的な看護業務や作業条件は Table 6 に示すごと く, 作業姿勢・動作では「中腰」「捻転」「曲げ」「重量 物取扱い」の頻度の多い群で高い age adjusted odds ratio を示しており，さらに腰痛症発症と取扱い重量と の間で量一反応関保が認められた．看護作業の負担との 関連では「食事などベッド上での看護」「䔟動や入浴の 介助」「与薬中注射の準備と処置」「血王や体温の測定と 観察」「患者への指道と説明」「記録や連絡，打合わせ」 などの各業務において精神的および肉体的に負担が強い とする群で統計的に有意に高い age adjusted odds ratio を示していた．その中でる，とりわけ「食事など ペッド上での看護」が肉体的に負担が強いとする群で高 い age adjusted odds ratioを示しており，前述の作 業姿勢や取扱い重量物の要因と合わせて考えると，患者 のペッド上での体位交換や抱き抱光などの動作中その祭 に生しる「中腰」「捻転」「曲げ」などの作業姿㢣拘束が 看護婦の腰痛症発症と強い関連があることをらかがわせ る.

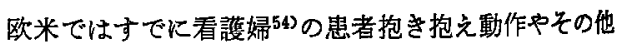
の女性労働者 ${ }^{55,56)}$ の重量物取扱い時の腰部負担之作業真 荷に関する基整的研究がなされており，直接看護業務の 際の患者抱き抱兄や移動介助時の安全性を配虑した技衔 指導や訓練手引きなど央践的な取組み年

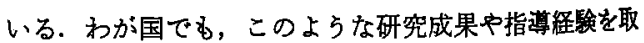
り入れ，日本の保健医療の実情に合わせた対策を行5必 要があうら.

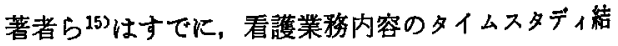
果により「与薬や注射の準備と処固」「血圧や体温の测 定と観察」「患者への指導之説明」「記録や連絡，打合力 せ」などの診察・治療の補助業務や間接看護業務がー日 の勤務時間の約 6 割から 7 割を占めると報告した. 日本 
Table 6. Age adjusted odds ratios for low back pain by work loads.

\begin{tabular}{|c|c|}
\hline Items & $\begin{array}{l}\text { Age adjusted odds } \\
\text { ratio }(95 \% \mathrm{CI})\end{array}$ \\
\hline \multicolumn{2}{|c|}{ Lack of breaks during working time } \\
\hline & $1.75(0.87-3.50)$ \\
\hline Duration of break time $(-)$ & $2.04(1.19-3.49)^{*}$ \\
\hline \multicolumn{2}{|l|}{ Working posture } \\
\hline Squatting sometimes & $1.77(0.36-8.78)$ \\
\hline Always & $10.54(2.23-49.92)^{* *}$ \\
\hline Twisting sometimes & $4.66(1.83-11.85)^{* *}$ \\
\hline Always & $15.27(6.01-38.74)^{* * *}$ \\
\hline Bending sometimes & $1.71(0.88-3.32)$ \\
\hline Always & $6.99(3.61-13.56)^{* * *}$ \\
\hline \multicolumn{2}{|l|}{ Heavy lifting } \\
\hline Sometimes & $1.48(0.40-5.50)$ \\
\hline Always & $4.92(1.45-16.73)^{* *}$ \\
\hline \multicolumn{2}{|c|}{$\begin{array}{l}\text { Weight of patients and equipment lifting and } \\
\text { moving }\end{array}$} \\
\hline $20-40 \mathrm{~kg}$ & $3.05(1.52-6.15)^{* *}$ \\
\hline $40-60 \mathrm{~kg}$ & $5.00(2.55-9.80)^{* * *}$ \\
\hline $60 \mathrm{~kg}-$ & $12.26(4.50-33.39)^{* * *}$ \\
\hline \multicolumn{2}{|c|}{ Intensity of nursing work loads } \\
\hline \multicolumn{2}{|c|}{ Caring for patients who are in bed } \\
\hline (Physical) & $9.01(4.81-16.86)^{* * *}$ \\
\hline (Mental) & $5.74(2.84-11.61)^{* * *}$ \\
\hline
\end{tabular}

Supporting patients when transporting and bathing them

(Physical) $5.74(3.29-10.02)^{* * *}$
(Mental)

$5.08(2.66-9.71) * * *$

Preparing drugs and injections, and treating (Physical) $4.42(2.19-8.90)^{* * *}$ (Mental) 4.14 (2.35- 7.29) $* * *$

Observing and monitoring patients' conditions (Physical) 2.60 (1.34- 5.06)** (Mental) $2.01(1.15-3.51)^{*}$

Instructing and explaining procedures to patients (Physical) $\quad 3.97(1.98-7.98)^{* * *}$ (Mental) $4.58(2.49-8.53)^{* * *}$

Recording observations and reporting these to co-workers, and arranging appointments for diagnostic tests

(Physical) 3.74 $(2.01-6.98)^{* * *}$ (Mental) 2.26 (1.21- 4.25)*

Cochran-Mantel-Haenszel test, ${ }^{*} p<0.05,{ }^{* *} p<$ $0.01, * * * p<0.001$.
Table 7. Age adjusted odds ratios for low back pain by working environments and psychological factors.

\begin{tabular}{cc}
\hline Items & $\begin{array}{c}\text { Age adjusted odds } \\
\text { ratio }(95 \% \mathrm{CI})\end{array}$ \\
\hline
\end{tabular}

Working environments and medical examinations

$\begin{array}{ll}\text { Noise } & 2.41(1.18-4.91)^{*} \\ \text { Cold } & 2.44(1.55-3.82)^{* *}\end{array}$

Lack of adequate lighting $2.89(1.67-4.98) * * *$

Small working space 2.26 (1.44-3.56)***

Blood and urine examinations

$2.33(1.48-3.66)^{* * *}$

Emotional state during work

Being irritated

$3.90(2.44-6.21)^{* * *}$

Feeling rushed

$2.01(1.24-3.25) * *$

Being bored

$3.36(1.91-5.93)^{* * *}$

Interpersonal relationship

Conflict with doctors $2.06(1.18-3.59)^{*}$

With chief nurses $\quad 1.73(1.09-2.75)^{*}$

With assistants $2.25(1.21-4.20)^{*}$

With patients and their family

$1.94(1.22-3.07)^{* *}$

Cochran-Mantel-Haenszel test, ${ }^{*} p<0.05, * * p<$ $0.01,{ }^{* * *} p<0.001$.

看護協会の看護婦機能委員会です 1983 年に同様の調查 結果をまとめ, 地域医療の展開や老人などに対する在宅 看護体制を展望するために、薬剂業務，事務処理作 業，連絡業務などの見直しを行ら必要があると報告して いる(0). 今回の研究結果では, 看護婦の診察・治療の補 助業務や間接看護業務は看護業務内容や看護の質などへ の影響もさることながら，腰痛症発症にも関連していた ことは注目しなければならない。

作業環境要因に関する検討では，従来より指摘されて きた腰瘦症発症に関連する温熱要因（寒さ）や作業スペ ース28 31)たけではなく，Table 7 に示すごとく騒音や照 明，血液・尿の検査などについても統計的に有意に高い age adjusted odds ratio を認めた. 騒音環境の要因が 医療現場，とりわけ看護現場で問題となるといら報告は 見当たらないが，騒音に伴ら仮眠や休息の妨げが腰痛症 発症に影響しているものと考えられる. 照明についても 同様の影響が推測されるが，さらに準・深夜勤務時の病 室内の照明の不備がベッド上の看護の遂行にあたって困 難をもたらす可能性についても考虑しておく必要があ る. 血液と尿については，採血や蓄尿，排泄の世話など 
Table 8. Age adjusted odds ratios for low back pain by problems with working life.

\begin{tabular}{lc}
\multicolumn{1}{c}{ Items } & Age adjusted odds ratio (95\% CI) \\
\hline Lack of time to rest & $2.02(1.16-3.52)^{*}$ \\
Difficult to pursue studies or take lessons privately & $2.01(1.21-3.33)^{* *}$ \\
$\quad$ outside of working hours & \\
Hard to take paid holidays & $2.47(1.37-4.44)^{* *}$ \\
Unable to eat meals on regular schedule & $3.10(1.56-6.14)^{* *}$ \\
Hard to take a day off even when ill & $2.85(1.53-5.31)^{* *}$ \\
Dreading coming to work & $4.10(2.45-6.85)^{* * *}$ \\
Disturbed due to environmental noise & $2.41(1.54-3.78)^{* * *}$ \\
Becoming very drowsy while working & $3.75(2.33-6.05)^{* * *}$ \\
Disturbed participation in community activities & $2.59(1.59-4.21)^{* * *}$ \\
Less time to enjoy family life & $2.40(1.46-3.93)^{* * *}$ \\
\hline
\end{tabular}

Cochran-Mantel-Haenszel test, ${ }^{*} p<0.05,{ }^{* *} p<0.01,{ }^{* * *} p<0.001$.

の看護業務のるつ腰部負担を示するのである.

作業中の心理状況や人間関係については「イライラす

る」「あきがくる」「せかされる」などの心理状態や医

師, 婦長・主任, 看護助手, 患者またはその家族との間 での葛藤によって, age adjusted odds ratioは統計的 に有意に高い值を示しており，看護業務が対人サービス 業務である限り，その職務要求や精神的ストレスも考慮 した上で, 総合的に評洒する必要性のあることを示唆し ている.

腰痛症発症と勤務生活上の問題点とに関する検討結果 は Table 8に示すごとく，「次の勤枒が気にかかる」「代 事中，ひどく眠い」「食事が不規則」「身体の具合が悪く ても休み難い」「また仕事かと気が重い」「騒音や人声で 睡眠が放げられる」「有給休樶が自由にとり難い」など で統計的に有意に高い, age adjusted odds ratio を認め た. 交代制勤務や看護婦不足が看護業務だけではなく， 日常生活にまで影響を及洼しており，腰痛症の回復を斿 げていることを示唆している。

\section{4. 腰痛症発症と職業性要因との総合的評価}

腰痛有訴 (症例) 群と腰痛非有訴 (対照) 群に対して, おの括のダミ一変数として 1 扰よび0を与えて目的変数 とし, 症例一対照研究によって統計的有意差の認められ た職業性要因 98 項目を説明変数として重回㷌分析のス テップワイズ法を用いて検討した. 重回帰分析結果にお いて, 偏 $F$ 值が 3.85 以上の 12 変数, 標準化偏回帰俰数 が 0.10 以上ないし -0.10 以下の 19 変数についても, おのおの別々にステップワイズ法を施行した結果は Table 9 に示すごとく，いずれの分析においても高い重 相関係数が得られたが，説明变数の数やモデルの適合性
といら観点を考慮すると, 説明変数に 12 ないし19 变数 を用いた場合の方が優れていた。

同じ説明変数を用いて行った判別分析結果は Table 10 に示すごとく, 腰痛有訴 (症例) 群と腰痛非有訴 (対照) 群との判別状況は正隼相関係数 0.65 , WILKS' $\Lambda 0.57$ であり，判別率は $83.9 \%$ と高い值を得た. また，变数 選択法を用いた解析結果では 39 変数が選択され，正準 相関係数 0.63 , WILKS' $A 0.60$, 判別率 $81.5 \%$ であ った.

さらに，調查表から得られたデータが質的なすのであ ることを考虑し，重回㷌分析法および判別分析法の解析 結果を確認するために，林の数量化 I 類および】類を用 いて同じモデルで検討した結果, 数量化 I 類およびI類 の相関比はともに 0.76 と高い值を示し, 数量化而類に おける判別率は $90.6 \%$ であった。これらの解析結果は 本研究で看護婦の腰痛症発症と職業性要因に関して設定 したモデルの妥当性を示するのであると考えられる。

腰痛症発症と職業性要因に関する重回帰分析のステッ プロイズ法拉よび判別分析法を用いた解析の結果，標準 化偏回㷌係数ないし偏 $F$ 値の高い職業性要因について注 目していくと Table 9 および Table 10 に示すごとく, 「食事などへッド上の看護（身体的負担）」「䘛じる（作 業姿勢)」「血圧や体温の測定と観察（精神的負担〉」「次 の勤務が気にかかる」「看護婦の資格」「仕事中にひどく 眠い」「与薬や注射の準備と処置（精神的負担）」「照明 (作業環境)」「看護婦同士の葛藤」「結核病棟（所属病 棟)」「取扱い重量」「護送患者数」「準夜回数」「夜勤回 数」「深夜の仮眠取得状況」「勤続年数」などがあげられ る. 多変量解析結果から抽出された職業性要因惊，症 
Table 9. Results of regression analysis for low back pain and occupational items.

\begin{tabular}{|c|c|c|}
\hline \multicolumn{3}{|c|}{$\begin{array}{lll}\text { Results of regression analysis using } 98 \text { items }(p<0.1) & \text { multiple } R: 0.6521 & R \text { square }: 0.4252 \\
\text { Results of regression analysis using } 12 \text { items }(F \text {-value }>3.85) & \text { multiple } R: 0.5607 & R \text { square }: 0.3144 \\
\text { Results of regression analysis using } 19 \text { items }(\beta>0.1, \beta<-0.1) & \text { multiple } R: 0.5838 \text { R square : } 0.3408\end{array}$} \\
\hline 19 Items & Beta & $\begin{array}{l}\text { Partial } \\
F \text {-value }\end{array}$ \\
\hline Caring for patients who are in bed (physical working load) & 0.2234 & 8.47 \\
\hline Twisting (working posture) & 0.1738 & 7.04 \\
\hline Dreading coming to work (working life) & 0.2105 & 13. 90 \\
\hline Assistant nurses (registration) & 0.1029 & 4.00 \\
\hline Poor lighting (working enviroment and medical examinations) & 0.1034 & 4.26 \\
\hline Number of nights worked $(16: 00-24: 00)$ & -0.1279 & 1.50 \\
\hline Becoming very drowsy while working (working life) & 0.1366 & 5. 78 \\
\hline Weight of patients and equipment lifting and moving & 0.1263 & 5.18 \\
\hline Conflict with other nurses (interpersonal relationship) & -0.1133 & 4.68 \\
\hline Tuberculosis ward (department category) & 0.1066 & 2.76 \\
\hline Observing and monitoring patients' conditions (mental working load) & -0.1709 & 4.27 \\
\hline Preparing drugs and injections, and treating (mental working load) & 0.1590 & 4.94 \\
\hline $\begin{array}{l}\text { Recording observations and reporting these to co-workers, and arranging } \\
\text { appointments for diagnostic tests (physical working load) }\end{array}$ & 0.1276 & 2.26 \\
\hline Blood and urine examination (working environment and medical examinations) & 0.1126 & 3.92 \\
\hline Lack of night naps during graveyard shift & 0.2226 & 5.20 \\
\hline Number of severe patients carried by stretcher & 0.1095 & 3.45 \\
\hline Being irritated (emotional state during work) & 0.1176 & 3. 39 \\
\hline Duration of nursing work & -0.1301 & 2.61 \\
\hline Number of nights worked & 0.1868 & 2.07 \\
\hline
\end{tabular}

例一対照研究においても極めて高い age adjusted odds ratio が認められ，両解析結果は同じ結論を導き出して いると考えられた.

これらの腰痛症発症に強く関与する職業性要因は「食 事などへッド上の看護（身体的負担）」「ねじる（作業姿 妿)」「取扱い重量」「護送患者数および結核病棟（所属 病棟)」などの直接看護業務の遂行に伴ら重量物取扱い や作業動作，作業姿勢に関する要因と「任事中にひどく 眠い「準夜回数」「夜勤回数」および「深夜の仮眠取得 状況」などの交代制勤務時の作業条件に関する要因，さ らには「血圧や体温の測定と観察（精神的負担）」「次の 勤務が気にかかる」「薬や注射の準備と処固（精神的 負担)」および「看護婦同士の葛藤」などの看護業務遂 行時の心理的・精神的負担の要因にまとめられる.すな わち，看護婦の腰痛症発症にかかわる職業性要因は，患 者ケアや対人サービスのあり方, 交代制勤務など看護業
務自体の特性と関連性を有していることが認められた。

$$
\text { V. 結論 }
$$

看護婦の腰痛症発症について，労働条件，作業環境， 交代制勤務をはじめとする労働態栐，介護負担や作業姿 淕なと゚の作業条件および勤務生活上の問題点などを把握 し, 腰痛症発症之職業性要因との間で疫学的な検討を行 い, さらに腰痛症発症と各要因との関連の強さを定量的 に評価した結果は，以下の 9 点に集約できる.

1) 看護業務は事務作業に比べ，中腰姿勢や腰部の捻 転および曲げなどの不自然な作業姿勢や患者などの抱き 抱えに代表される重量物取扱い動作の頻度が有意に多 く，腰痛症をはじめとする筋骨格系疾患の発症するリス クの高い職場であることを認めた.

2) 看護婦と事務員との間の腰痛症有訴状況を比較す ると,看護婦の方が腰痛症有経験者の比率, 現在就よび先 
Table 10. Results of discriminant analysis for low back pain and occupational items.

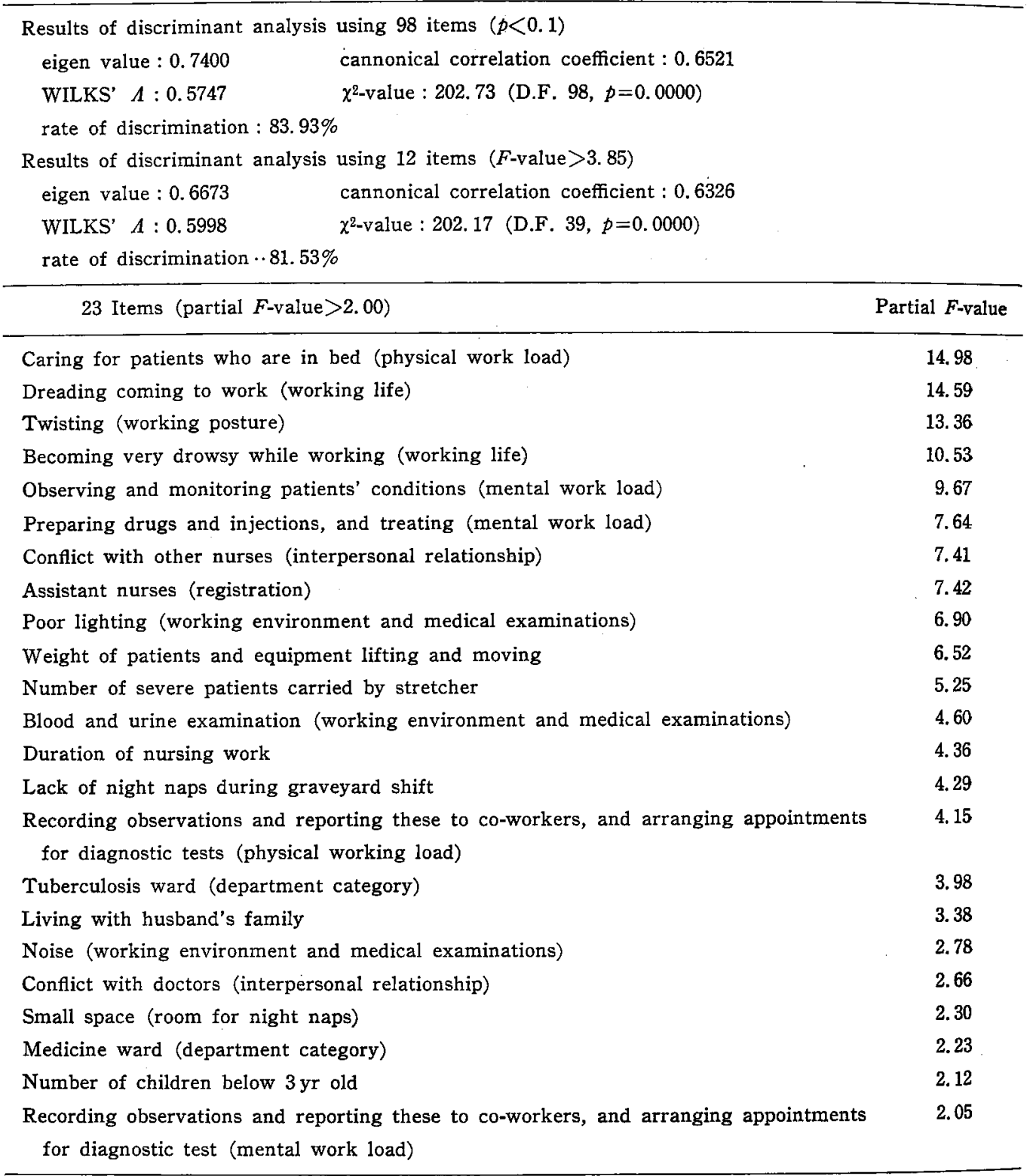

月1か月の腰痛症有訴率のいずれにおいても有意に高い 訴光率であった，また，両群ともに慢性発症型の腰痛症 の比率が最も多かったが，看護婦では腰痛症経験者の 4 分の 1 が急性発症型の腰痛症で，現在の腰痛症の程度に ついても，休業・休䕀が必要である，ないしはかなりつ らいとする比率が高く，看護㷌の腰痛症発症の特改は急 性発症であり, 重症度の高い腰痛症であることを認め
た.

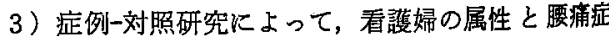
発症との関連について検討した結果，准看脬婦ゆ内科， 整形外科，脳外科，精神科怙よび結核病棟の病棟看荍婦 で統計的に有意に高い odds ratio そ示しこれらの要 因に伴ら看護業務内容や作業条件が看護婦の腰痛庭発症 と関連していることを認めた. 


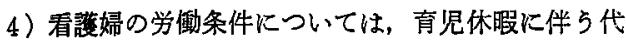
替要員の未配置，年次休㗇の取得困難，担・謢送ない乙 重症な患者数の增加，さらには準・深夜の休想や深夜の 仮眠の取得困難，仮眠設備の未設置，設置されている仮 眠設備の悪循環など交代制勤務に関して問題点のある場 合に，腰痛症発症関する age adjusted odds ratio 統計的に有意に上昇することを認めた。

5) 看護業務や作業条件では，中腰姿繁，腰部の捻転 や曲げなどの不自然な作業姿勢・動作，重量物の取扱い 频度や取扱い重量，さらに具体的な看護作業では食事な ぞヘッド上での看護, 移動や入浴の介助，与薬や注射の 準備と処䈯, 血压や体温の測定と観察, 患者への指導と 説明，記録や連絡，打合わせなどの各業務に执いて精神 的ないし肉体的な負担の程度が腰痛症発症に強く関連し ていることを認めた。

6）作業環境関しては，温熱や作業スペース，螵 音, 照明など多くの要因について統計的に有意に高い age adjusted odds ratio を認めた.

7）作業中の心理状況や人間関係については，イライ ラする，あきがくる，せかされるなどの心理状態や医 師，婦長・主任，看護助手，患者またはその家族との間 での䓪藤がある場合に，統計的に有意に高い age adjusted odds ratio を示し, 看護婦の職務要求や精神的スト レスなどを腰痛症発症に関連していることを認めた.

8）勤務生活上の問題点では，不規則な食事や不十分 な睡眠・休㗇などが腰痛症発症と関連し，交代制勤務や 看護婦不足泟伴 5 学働条件や作業条件が腰痛症の回復を 妨げていることを認めた.

9）看護婦の腰涌症発症にかかわる職業性要因につい ては，多変量解析を用いて総合的に検討した結果，直接 看護業務に代表される患者ヶつを行ら時の重量物取扱い

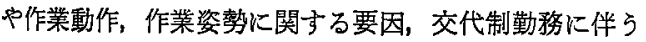
作業条件に関する要因, 看護業務遂行時の心理的・精神 的な要因が関連していることを認めた。

以上の結果から，看護婦の腰痛症発症にかかわる職業 性要因との関連性および定量的な関連の強さについて明 らかにしえた.

本論文の要旨の一部恃，日本産業街生学会第 32 回腰满研究

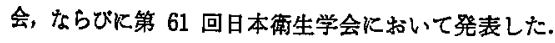

\section{文献}

1) 厚生省，編. 昭和62年版厚生白書. 東京: 厚生統計協会, $1988: 109-135$.

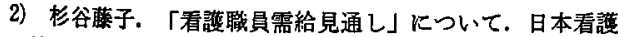
協会，編．平成 2 年版看護白毒. 東京 : 日本看護協会出版
会, $1990: 99-110$.

3）斉藤 一，女子の時間外労㒋と深夜業の規制の意義に関 する労働科学的基礎. 学働科学 $1974 ; 50: 483-508$.

4）松本一弥，笹川七三子，川森正夫. 交代勤務制が病院看

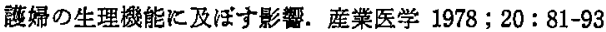

5）松本一弥. 衛生学からみた夜勤・交代制勤務. 病院 $1983 ; 42: 408-414$.

6）久繁徳，大原綮志. 病院看護婦の疲学と健康状態につ いて 第 1 糄 看護婦の疲学と健康状態の特徽. 学働科学 $1985 ; 61: 517-528$.

7）啝岡光昭. 然兑つき症候群作った看護婦の㑯向分析か b. 看護学䊒誌 $1984 ； 48: 993-997$.

8）猪下 光. 看愎婦のパーンアウト現象とその発生要因に 関す方文献的研究. 看護展望 $1986 ； 11: 49-55$.

9）南裕子，山本あい子，太田喜久子，ほか。看萑婦のむ えつき現象とストレスおよびンーシャルサポートの関俰に ついて. 聖路加看護大学紀要 $1987 ; 12: 26-34$.

10）松野か㤬る. 看護䀦にみられる BURNOUT とその要 因に関市る研究. 昭和医学会雅誌 $1987 ; 47: 383-391$.

11）增子詠一，山岸みどり，岸 玲子，三宅浩次. 医師・看護 婦など対人サービス職業従事者の「然えつき症候群」(1) 産業医学 $1989 ; 31: 203-215$

12) Hisashige A, Koda $S$, Kurumatani $N$, et al. Occupational influences on Burnout phenomenon among hospital nurses. J UOEH 1989; 11 : 454-466.

13) Koda $S$, Hisashige A, Kurumatani $N$, et al. A study of Burnout among hospital nurses. J UOEH $1989 ; 11: 604-608$.

14）影山隆之，榡俊夫. 病院勤務看榙職者の精神衙生. 産 業医学 $1991 ; 33: 31-44$.

15）甲田茂樹，久繁哲徳，車谷典男，ほか，看膵単位と看護 労働. 疲労之休着の科学 $1988 ; 4: 61-74$.

16) Cust G, Pearson JCG, Mair A. The prevalence of low back pain in nurses. Int Nurs Rev 1972; $19: 209-212$

17) Dehlin O, Hedenrud B, Horal J. Back symptoms in nursing aides in a geriatice hospital. Scand $\mathbf{J}$ Rehabil Med 1976; $8: 47-53$.

18) Stubbs DA, Buckle PW, Hudoson MP, et al. Back pain in the nursing profession : I. epidemiology and pilot methodology. Ergonomics 1983; $26: 755-765$.

19) Stubbs DA, Buckle PW, Hudoson MP, et al. Back pain in the nursing profession: II. the effectiveness of training. Ergonomics $1983 ; 26: 767-$ 779.

20) Owen BD, Damron CF. Personal characteristics and back injury among hospital nursing personal. Res Nurs Health $1984 ; 7: 305-313$.

21) Videman $T$, Nurminem $T$, Tola $S$, et al. Lowback pain in nurses and some loading factors of work. Spine $1984 ; 9: 400-404$.

22) Harber P, Billet E, Gutowski M, et al. Occupational low-back pain in hospital nurses. J Occup Med $1985 ; 27: 518-524$

23) Skovron ML, Mulvihill MN, Sterling RC, et al. Work organization and low back pain in nursing personal. Ergonomics 1987; 30:359-366.

24) Uhl JE, Wilkinson WE, Wilkinson CS, et al. Aching back? : a glimpse into the hazard of nursing. AAOHN J $1987 ; 35: 13-17$.

25) McAbee RR. Nurses and back injuries. AAOHN 
J $1988 ; 36: 200-209$.

26) Kelsey JL. Epidemiology of musculoskeletal disorders. New York : Oxford University Press, 1982.

27) Pope MH, Frymoyer JW, Andersson G. Occupatinal low back pain. New York: Praeger, 1984.

28）青山英康，明石 謙，共編. 新版 職業性腰痛 予防か

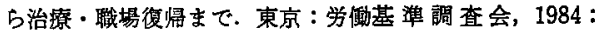
143-214.

29）青山芙康，井谷 徹. 腰痛症.三浦豐彦活か，編．現代 労働衛生ヘンドブック.川崎：労倒科学研究所, 1988 : 964-978.

30）青山芙康，井谷 徹. 各疾患の病熊とその治療法. 宝田 景久ほか糄. 疫学, 因説整形外科診断治療諥座 1 腰痛. 東 京：メシカルビュー社, $1989: 96-103$.

31）甲田茂樹，姿努拘束と職業性腰痛症．労働の科学 1989 ; $45(9): 14-17$.

32）Korn T (都留信子，訳)。ナーシングキームリーダーシ ッブ，第 2 版. 東京：医学書院，1969.

33）西元勝子，杉野元子. 看護チームの有成上運営 継続性 のある看讙をめざして，東京：医学軎院， 1985.

34）厚生省健康政策局看護課，監修. 平成元年看護関俰統計 資料集. 東京：日本看讙協会出版会， 1989.

35）青山英康. 小衛生学. 京都 : 金芳堂, $1976: 267-280$.

36）日本産業衛生学会腰痛研究会. 腰痛委員会報告. 産業医 学 $1973 ; 15: 297-304$.

37) Nackemson AL, Andersson GBJ. Classification of low-back pain. Scand J Work Environ Health $1982 ; 8: 134-136$.

38) MacMahon B, Pugh TF. Epidemiology principles and methods. Boston : Little Brown, 1970 : 1746.

39）Fisher FD (春日 齐, 重田定羲, 監訳).プログラム 学習による度学入門. 東京 : 庴川書店 $1978: 45-75,140-$ 148.

40) Deming WE. Some theory of sampling. New York : Dover, 1966 : 213-246.

41) Anderson S, Auquier A, Hauk WW, et al (重松 冕造, 柳川 洋, 監訳)。淩学・臨床医学に护りる比較研 究の統計学. 東京: ソフトサイェンス社, $1982: 73-145$.

42) Mausner JS, Kramer S. Epidemiology-an introductory text. Toronto: WB Saunders, 1985:
154-194.

43) Fletcher RH, Fletcher SW, Wagner EH. Clinical Epidemiology. Baltimore : Williams \& Wilkins, 1988 : 188-207.

44) Schlesselman JJ. Case-control studies. New York : Oxford University Press, 1982 : 181-196.

45）林知已夫, 駒沢 勉. 数量化理論とデー夕处理. 東京： 朝倉害店, 1982.

46）西里静彦. 質的データの数量化一双対尺度法とその㐫用 一. 東京 : 朝倉毒店, 1982.

47）田中 豊, 脇本和昌. 多変量統計解析法. 京都 : 現代数 学社, 1983:137-178.

48）垂水共之，西脇二一，石田千代子，法加。新版 SPSSX II 解析編 1 、東京 : 東洋経济社, 1990 .

49）小木和孝. 睡眠りズムの位相と交替制勤務. 労勘の科学 $1975 ; 30(8): 9-14$.

50）小木和孝. 労做時間（斉藤 一，監修），川绮：労湖科 学研究所 1981:68-89.

51）酒井一博, 渡辺明应，大西徳明，法か，夜勤の疲労回復 に有効な仮眠条件. 労使科学 $1984 ; 60$ :451-477.

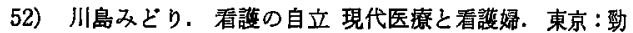
草書房, 1977.

53）川島みどり.看蓝の自立 2 看護婦の労倬と仕事. 東京: 勁草書房, 1982.

54) Dehlin O, Jaderberg E. Perceived exertion during patient lifts. Scand J Rehabil Med 1982; 14: 11-20.

55) Snook SH, Ciriello VM. Maximum weights and work loads acceptable to female workers. J Occup Med $1974 ; 16: 527-534$.

56) David GC. Intra-abdominal pressure measurements and load capacities for females. Ergonomics $1985 ; 28: 345-358$.

57) Scholey $M$. Patient handling skills. Nurs Times $1984 ; 80: 25-27$.

58) Wright $B$. Lifting and moving part $I$ : an in vestigation and commentary. Nurs Times 1981 a; $77: 1962-1965$.

59) Wright $B$. Lifting and moving part II : training and management. Nurs Times $1981 \mathrm{~b} ; 77: 2025-$ 2028.

60）日本看護協会, 編. 病院看護機能評価子ニ $=7 ル$. 東 京：日本看護協会出版会, 1987.

著者の信通先：甲田茂樹，干700 岡山市鹿田町 2-5-1 岡山大学医学部衛生学教室 Reprint requests to Department of Hygiene and Preventive Medicine, Okayama University School of Medicine, 5-1, Shikata-cho 2-chome, Okayama, 700 Japan (S. Koda) 